\title{
THE EFFECTS OF SIVELESTAT SODIUM ON SEVERE ACUTE PANCREATITIS COMPLICATIONS
}

\author{
KEXING ZHOU *, SIQUAN ZHANG ${ }^{\# *}$, SHUGUO LI, JIAYU HAN, YAN YAO, XI ZHAO, \\ QINYAO QI
}

Intensive Care Unit, Xixi Hospital, Hangzhou, 310023, China

*corresponding author: zhangsiquancare@yeah.net

\#Authors with equal contribution

Manuscript received: February 2018

\begin{abstract}
Acute pancreatitis represents a medical emergency and untreated can lead to serious complications. This study aimed to investigate the therapeutic effect of sivelestat sodium on the renal injury induced by severe acute pancreatitits and its mechanism of action. Ninety Sprangue-Dawley male rats were randomly divided into 3 groups: a sham operation group (SO group), an acute pancreatitis model group (SAP group) and sivelestat sodium treatment group (SS group), 30 rats per group. The rats from each group were randomly divided into three subgroups $(6 \mathrm{~h}, 12 \mathrm{~h}$ and $24 \mathrm{~h}$ time points evaluation), 10 animals per subgroup. At each time point, serum amylase (AMY), creatinine (Cr), blood urea nitrogen (BUN), serum TNF- $\alpha$, IL-6, and neutrophil elastase (NE) levels were determined, pancreas and kidney tissue were evaluated histopathologically and NF$\mathrm{kB}$ activity was determined in the renal tissue. In the SAP and SS groups, the levels of AMY, Cr, BUN, NE, TNF- $\alpha$, IL-6 were increased compared with the SO group. The pathological scores of pancreas and kidney were increased in the SAP and SS groups compared to the SO group at each time point $(\mathrm{p}<0.05)$. In addition, the level of NF-kB activation in renal tissue was gradually increased $(\mathrm{p}<0.05)$. Compared with the SAP group, in SS rats the levels of AMY, Cr, BUN, NE, TNF- $\alpha$, IL-6 decreased significantly at each time point. NF-kB activity was lower in the SS group compared with SAP also the integrity of pancreatic and renal tissue was less affected than in the case of SAP rats $(p<0.05)$. Sivelestat sodium can effectively improve the function of damaged kidney in the course of severe acute pancreatitis. Its mechanism of action is related to the reduction of inflammatory factors like TNF- $\alpha$ and IL-6, through the inhibition of NE release and to the blockage NF-kB pathway activators in the renal tissue, in order to avoid secondary inflammatory injuries of the tissue.
\end{abstract}

\section{Rezumat}

Pancreatita acută reprezintă o urgență medicală și netratată poate duce la complicații grave. Acest studiu a urmărit investigarea efectului terapeutic al sivelestatului sodic asupra leziunii renale induse de pancreatita acută și mecanismul său de acțiune. Nouăzeci de șobolani masculi CD-SD au fost împărțiți în mod aleatoriu în 3 grupuri: un grup de control (grupul SO), grupul cu pancreatită acută (grupul SAP) și grupul tratat cu sivelestat sodic (grupa SS), 30 de şobolani per grup. Aceștia au fost repartizați aleatoriu în trei subgrupe $(6 \mathrm{~h}, 12 \mathrm{~h}$ și $24 \mathrm{~h}), 10$ animale/subgrup. S-au determinat amilaza serică (AMY), creatinina (Cr), ureea (BUN), TNF- $\alpha$, IL-6 și neutrofil-elastaza (NE) din sânge, s-au evaluat histopatologic țesutul pancreatic și renal, iar NF-kB a fost determinat pe țesut renal. În grupurile SAP și SS nivelurile de AMY, Cr, BUN, NE, TNF- $\alpha$, IL-6 au crescut în comparație cu grupul SO. Scorurile patologice ale pancreasului și rinichilor au fost crescute în grupurile SAP și SS în comparație cu grupul SO la fiecare determinare $(\mathrm{p}<0,05)$. În plus, nivelul activării NF-kB în țesutul renal a crescut treptat $(\mathrm{p}<0,05)$. În comparație cu grupul SAP, în grupul SS nivelurile de AMY, Cr, BUN, NE, TNF- $\alpha$, IL-6 au scăzut semnificativ. Activitatea NF-kB a fost mai mică în grupul SS în comparație cu SAP, de asemenea, integritatea țesutului pancreatic și a celui renal a fost mai puțin afectată decât în grupul SAP $(\mathrm{p}<0,05)$. Sivelestatul sodic poate îmbunătăţi în mod eficient funcția renală în cazul pancreatitei acute. Mecanismul său de acțiune este legat de reducerea factorilor inflamatori TNF- $\alpha$ și IL-6, prin inhibarea eliberării NE și blocarea activării căii NF-kB în țesutul renal, pentru a evita leziunea inflamatorie secundară a țesutului.

Keywords: severe acute pancreatitis; kidney injury; sivelestat sodium

\section{Introduction}

Acute pancreatitis (AP) is an inflammatory reaction accompanied by oedema, haemorrhage and necrosis of the pancreatic tissue. Acute pancreatitis is one of the most common surgical acute abdomen [1, 2]. Acute pancreatitis represents a medical emergency and untreated can lead to serious complications including pseudocysts, infections, kidney failure, breathing problems, diabetes, malnutrition and even pancreatic cancer [3]. An appropriate treatment for acute pancreatitis does not exist, the current guidelines presenting different therapeutic schemes that focus on the symptoms and the management of the complications [3]. Neutrophil elastase (NE) is a serine protease that determines persistent neutrophilic inflammation by accelerating pro-inflammatory 
cytokines production. Its concentration was associated with the progression of acute pancreatitis [4]. Sivelestat is a selective neutrophil elastase inhibitor. In a model of pulmonary tracheal fibrosis, it was found that sivelestat can inhibit the excessive production of connective tissue (anti-fibrosis), decreases the infiltration of polymorphonuclear leukocytes (PMN) in to the inflammatory site, and down-regulates the expression of IL-1 $\beta$, platelet-derived growth factor (PDGF), macrophage inflammatory protein-2 (MIP-2) and insulin-like growth factor-1 (IGF-1) mRNA [5]. It has been reported that sivelestat sodium can also protect the brain from cerebral ischemia, haemorrhage and cerebral vascular obstruction, reduces neutrophils infiltration, regulates the inflammatory reactions, antagonizes the reactive oxygen species, reduces the oedema, diminished the cerebral infarction area and improves brain function [6]. One of the main mechanisms of severe acute pancreatitis (SAP) is the systemic inflammatory response syndrome caused by the over-activation of leukocytes. Therefore, sivelestat sodium may be helpful for the improvement of SAP, which is of great significance for the progression of the disease and treatment $[7,8]$. This study aimed to investigate the potential therapeutic effect of sivelestat sodium on the renal injury induced by SAP and its mechanism of action.

\section{Materials and Methods}

Sodium taurocholate (Amresco Company, Guangzhou Xueyou Biotechnology Company, China) (5\% standard solution was prepared with normal saline solution); sivelestat sodium powder-injection (Shanghai Huilun Life Science and Technology Co., Ltd, China); 10\% chloral solution (The First Clinical Medical College of Jinan University, China); rat tumour necrosis factor $\alpha$ (TNF- $\alpha$ ) ELISA (Enzyme Linked Immunosorbent Assay) kit (Bio-Techne, Minneapolis, USA); rat interleukine-6 (IL-6) ELISA kit (Bio-Techne, Minneapolis, USA); rat neutrophil elastase (NE) ELISA Kit (BioTechne, Minneapolis, USA); nuclear factor NF-kB p65 polyclonal antibody (Bio-Techne, Minneapolis, USA); 3,3' Diaminobenzidine (DAB) chromogenic agent (DAKO biotech Co., Ltd.., Santa Clara, USA); ChemMate $^{\mathrm{TM}}$ DAKO Envision ${ }^{\mathrm{TM}}$ (DAKO biotech Co., Ltd.., Santa Clara, USA).

Animals

90 healthy male SPF (specific-pathogen-free) grade, Sprangue-Dawley (Rattus Norregicus) rats with a body weight of 250 - $300 \mathrm{~g}$ were included in the study. After acclimatization to the standard laboratory conditions, $25^{\circ} \mathrm{C}$ temperature and $60 \%$ relative humidity, with 12 hours light/dark cycle, the animals were randomly divided into 3 groups: the sham operation group (SO group), the acute pancreatitis model group (SAP group) and sivelestat sodium treatment group (group SS), 30 animals per group.
The SS group received sivelestat sodium in doses of $30 \mathrm{mg} / \mathrm{kg}$ body weight injected intra venous in penile dorsal vein. The SO and SAP groups received normal saline solution. The rats from each group were randomly divided into three subgroups $(6 \mathrm{~h}, 12 \mathrm{~h}$ and $24 \mathrm{~h}$ evaluation), 10 animals per subgroup. The experiments were approved by the Ethics Committee of Xixi Hospital, Hangzhou, China and all the procedures were according to the international directives regarding animal experiments [8].

The severe acute pancreatitis (SAP) animal model The experiments were performed in Jinan University, China. After 2 weeks acclimatization period, the animals were fastened for 12 hours, having access only to free drinking water. The rats were anesthetized with $10 \%$ chloral hydrate $(3 \mathrm{~mL} / \mathrm{kg}$ body weight) injected intraperitoneally, and were fixed on the operation board. The surgical instruments were sterilized by high pressure boiler. The SAP rat model was established by retrograde pancreatic duct puncture: i) the skin from the operation area was disinfected with iodine containing alcohol; ii) the abdominal straight line incision was selected, and an incision of $3 \mathrm{~cm}$ length was made; iii) bile duct occlusion was confirmed (the gastric pouch was found along the direction of the lower intestine), and the hepatic hilar region was occluded with a small artery clamp; iv) the white enlargement of the junction between the pancreaticbiliary duct and the duodenum was found (this is the opening of the duodenal papilla). No. 4 flat tip was used to open the puncture tip of the duodenal wall with a slow needle through the expansion of the pipeline along the direction of migration. The retrograde insertion of the pancreatic duct was about $0.6 \mathrm{~cm}-0.8 \mathrm{~cm}$. No-damage small artery clamp was used to prevent the slide out of the needle. A solution of $5 \%$ sodium taurocholate was injected $(0.1 \mathrm{~mL} / \mathrm{min})$. The pancreatic duct was observed for 2 - 3 minutes. If there was obvious oedema and bleeding in the white gland, then the syringe need was removed. The procedure should avoid the injection of bile duct that damages the model. If there was no obvious haemorrhage and oedema of the pancreas after the drug injection, it can be repunctured at the distal part of the original puncture site. After confirming the non-bleeding site, the nonblocking clamp was removed and the bowel was reset after the closure of the abdomen. In order to maintain the balance of body fluids, all rats received normal saline solution (30 $\mathrm{mL} / \mathrm{kg}$ body weight) subcutaneously. In the sham operation group, the pancreas was scraped with the knife handle three times after laparotomy, and then the abdomen was closed.

Samples collection and processing

Each group was subdivided in 3 subgroups investigated after $6 \mathrm{~h}, 12 \mathrm{~h}$ and $24 \mathrm{~h}$ from the procedure (10 rats in each subgroup). After $10 \%$ chloral hydrate anaesthesia, 
FARMACIA, 2018, Vol. 66, 6

the blood was collected from the abdominal aorta and centrifuge at $3000 \mathrm{rpm}$ for 15 minutes. The supernatant was used for the determination of TNF- $\alpha$, IL-6, and NE, AMY (serum amylase), Cr (Creatinine), BUN (Blood Urea Nitrogen). The AMY, Cr and BUN levels were determined with Hitachi 7600 Automatic Biochemical Analyzer, Japan.

TNF- $\alpha$ levels were determined by solid phase double anti sandwich (ELISA) method according to the manufacturer specification using Rat TNF- $\alpha$ ELISA Kit (Hangzhou Union Biotechnology Co., Ltd in Zhejiang, China).

IL-6 serum levels were determined by ELISA method according to the manufacturer specification using Rat IL-6 ELISA kit (Hangzhou Union Biotechnology Co., Ltd Zhejiang, China).

NE serum levels were determined by ELISA method according to the manufacturer specification using
Rat neutrophil elastase (NE) ELISA kit (Hangzhou Union Biotechnology Co., Ltd Zhejiang, China).

The level of NF-kB in rat kidney tissue was detected by ChemMate DAKO Envision TM immunohistochemical kit (DAKO A/S, Denmark). The slices of each experimental group were taken with Olympus DP71 photographic system at low and high focal lengths. The data should be recorded and saved after reading.

After blood collection the animals were sacrificed and the left kidney and pancreas were taken. From the pancreas there were choses pieces of $1 \mathrm{~cm} \times 1 \mathrm{~cm}$ from the pancreatic head and the same from the left kidney. The pieces were fixed in formaldehyde for $24-48 \mathrm{~h}$ and then the tissue sections were made and stained with haematoxylin eosin (HE). It was scored according to Table I and Table II.

Table I

SAP Pathological Injury Scoring Standard (Pancreas)

\begin{tabular}{ccc}
\hline Index & Score & Pathological changes \\
\hline \multirow{3}{*}{ Oedema } & 0 & No oedema \\
& 1 & Interlobular regional oedema \\
& 2 & Interlobular diffuse oedema \\
& 3 & Acellular swelling and enlargement of interlobular septum \\
Inflammatory cell infiltration & 4 & Obvious lobular septation \\
\hline & 0 & Leukocyte $0 \sim 1 / \mathrm{HP}$ \\
& 1 & Leukocyte $2 \sim 10 / \mathrm{HP}$ \\
& 3 & Leukocyte $11 \sim 20 / \mathrm{HP}$ \\
Haemorrhage & 4 & Leukocyte $21 \sim 30 / \mathrm{HP}$ \\
& 0 & No haemorrhage in parenchyma \\
& 1 & Substantial haemorrhage $0 \% \sim 25 \%$ \\
& 2 & Substantial haemorrhage $25 \% \sim 50 \%$ \\
& 3 & Substantial haemorrhage $50 \% \sim 75 \%$ \\
& 4 & Substantial haemorrhage $>75 \%$ \\
\hline \multirow{3}{*}{ Necrosis } & 0 & No necrosis \\
& 1 & Substantial haemorrhage $11 \% \sim 20 \%$ \\
& 2 & Substantial haemorrhage $21 \% \sim 30 \%$ \\
& 3 & Substantial haemorrhage $>30 \%$ \\
\hline
\end{tabular}

Table II

Scoring criteria for pathological changes of renal tissue in SAP Grade Pathological changes

\footnotetext{
Glomerular structure is normal, renal tubular epithelium is turbid and swollen, cell boundary is clear, official cavity exists, and there is no protein substance, interstitial blood congestion, oedema.

Glomerular congestion or ischemic changes, renal tubular epithelial degeneration, blurred cell boundaries, narrowing or occlusion of the official cavity or full of protein oedema, occasional renal tubular epithelial necrosis, interstitial congestion, and oedema Grade II + lamellar tubular epithelial necrosis
}

\section{Statistical analysis}

The experimental data was analysed using SPSS 13 Windows system. Data were expressed as average \pm standard deviation. The differences between groups were assessed using Student's t test. Single factor variance was employed in order to analyse the comparison between two time points in a single group. $\mathrm{p}<0.05$ was considered as statistical significant.

\section{Results and Discussion}

The serum biochemical parameters (AMY, BUN, Cr) evaluation

The serum levels of AMY, BUN and $\mathrm{Cr}$ in the groups at different time points are shown in Table III and Figure 1. 
Table III

Serum amylase, BUN and Cr levels at different time points $(6 \mathrm{~h}, 12 \mathrm{~h}, 24 \mathrm{~h})$ in the studied groups

\begin{tabular}{|c|c|c|c|c|c|c|c|c|c|c|}
\hline \multirow{2}{*}{ Groups } & \multirow{2}{*}{$\mathrm{n}$} & \multicolumn{3}{|c|}{ Serum amylase $(\mathrm{U} / \mathrm{L})$} & \multicolumn{3}{c|}{ BUN $(\mathrm{mmol} / \mathrm{L})$} & \multicolumn{3}{c|}{$\mathrm{Cr}(\mu \mathrm{mol} / \mathrm{L})$} \\
\cline { 3 - 10 } & & $6 \mathrm{~h}$ & $12 \mathrm{~h}$ & $24 \mathrm{~h}$ & $6 \mathrm{~h}$ & $12 \mathrm{~h}$ & $24 \mathrm{~h}$ & $6 \mathrm{~h}$ & $12 \mathrm{~h}$ & $24 \mathrm{~h}$ \\
\hline \multirow{2}{*}{$\mathrm{SO}$} & 10 & $1105.24 \pm$ & $1192.05 \pm$ & $1163.25 \pm$ & $6.25 \pm$ & $6.94 \pm$ & $6.79 \pm$ & $32.20 \pm$ & $34.27 \pm$ & $31.17 \pm$ \\
& & 105.36 & 103.12 & 134.27 & 0.96 & 0.27 & 0.81 & 4.67 & 6.45 & 6.51 \\
\hline \multirow{2}{*}{$\mathrm{SAP}$} & 10 & $5905.02 \pm$ & $6556.37 \pm$ & $8146.29 \pm$ & $8.65 \pm$ & $15.15 \pm$ & $24.05 \pm$ & $67.28 \pm$ & $96.28 \pm$ & 141.17 \\
& & 397.57 & 497.78 & 552.76 & 0.17 & 2.10 & 6.21 & 5.15 & 12.02 & \pm 21.51 \\
\hline \multirow{2}{*}{$\mathrm{SS}$} & 10 & $5519.78 \pm$ & $5643.82 \pm$ & $6954.91 \pm$ & $8.10 \pm$ & $10.17 \pm$ & $15.17 \pm$ & $61.67 \pm$ & $72.18 \pm$ & $103.4 \pm$ \\
& & 314.07 & $368.85^{*}$ & $572.68^{*}$ & $0.47^{*}$ & $1.36^{*}$ & $1.36^{*}$ & $2.65^{*}$ & $9.54^{*}$ & $10.57^{*}$ \\
\hline
\end{tabular}

$* \mathrm{p}<0.05$ SAP group compared to the SS group

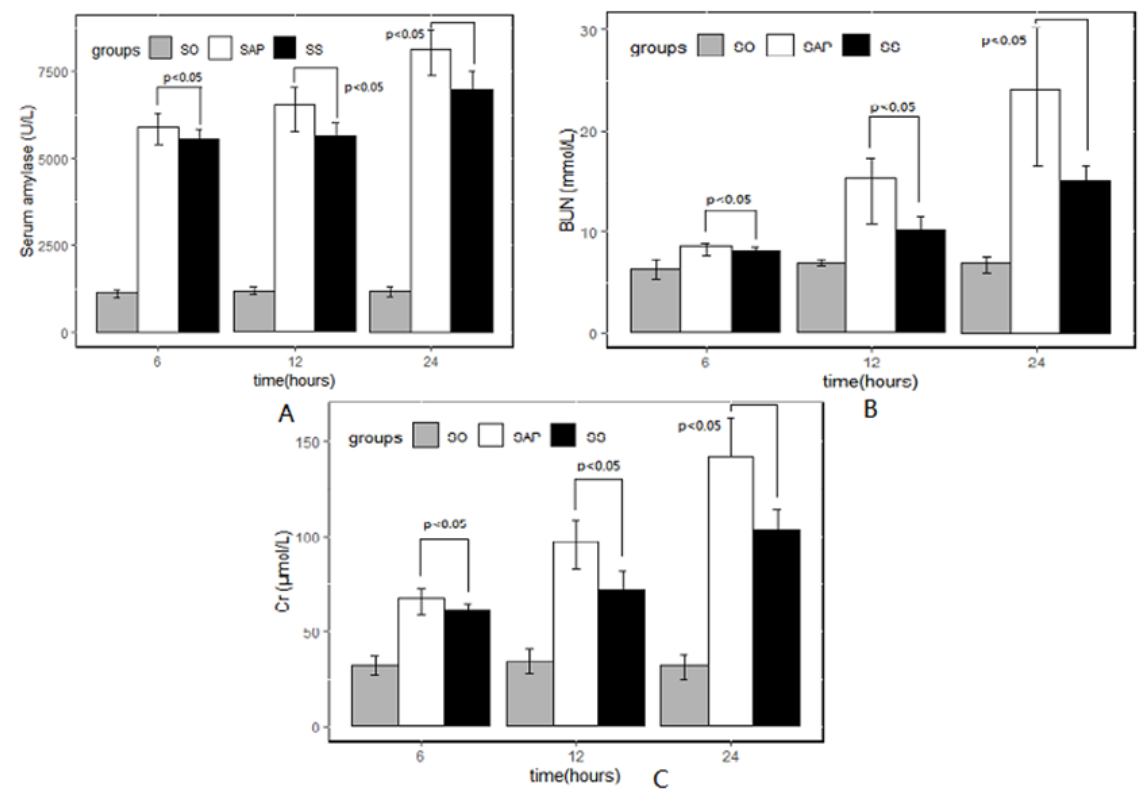

Figure 1.

Serum amylase, BUN and Cr levels at the three (6 h, 12 h, $24 \mathrm{~h})$ time points in each studied group

The AMY levels in the SO group was almost constant for each time point with no significant fluctuations $(\mathrm{p}>0.05)$. Compared to the SO group, the serum AMY was significantly higher in the SAP and SS group for the same time point $(\mathrm{p}<0.05)$. The AMY levels increased significantly with time. Compared with the SAP group, the AMY level at $6 \mathrm{~h}$ in SS group was not significantly different $(p>0.05)$. The AMY levels at $12 \mathrm{~h}$ and $24 \mathrm{~h}$ points decreased in the SS group compared with the SAP group $(\mathrm{p}<0.05)$ (Table III and Figure 1A).

The BUN and Cr levels in SO group were almost constant for each time point. The BUN and $\mathrm{Cr}$ levels significantly increased in the SAP and SS groups compared to the SO group $(p<0.05)$. The same parameters decreased in the SS group at each time point $(\mathrm{p}<0.05)$ compared to the SAP rats (Table III and Figure 1B and Figure 1C).

Immunological parameters (TNF- $\alpha, I L-6, N E)$ evaluation Serum TNF- $\alpha$ level in the SO group was almost constant for all the 3 time points $(p>0.05)$. In SAP and SS groups TNF- $\alpha$ increased compared to the SO rats for each time point $(\mathrm{p}<0.05)$. TNF- $\alpha$ levels in the SS group decreased compared with SAP group at each time point $(\mathrm{p}<0.05)$ (Table IV, Figure 2A).

Table IV

Serum TNF- $\alpha$, IL- 6 and NE levels at different time points in the groups

\begin{tabular}{|c|c|c|c|c|c|c|c|c|c|c|}
\hline \multirow{2}{*}{ Groups } & \multirow{2}{*}{$\mathrm{n}$} & \multicolumn{3}{|c|}{ TNF- $\alpha(\mathrm{pg} / \mathrm{mL})$} & \multicolumn{3}{c|}{ IL-6 $(\mathrm{pg} / \mathrm{ml})$} & \multicolumn{3}{c|}{$\mathrm{NE}(\mathrm{pg} / \mathrm{ml})$} \\
\cline { 3 - 11 } & & $6 \mathrm{~h}$ & $12 \mathrm{~h}$ & $24 \mathrm{~h}$ & $6 \mathrm{~h}$ & $12 \mathrm{~h}$ & $24 \mathrm{~h}$ & $6 \mathrm{~h}$ & $12 \mathrm{~h}$ & $24 \mathrm{~h}$ \\
\hline \multirow{2}{*}{$\mathrm{SO}$} & \multirow{2}{*}{10} & $23.14 \pm$ & $22.30 \pm$ & $22.45 \pm$ & $45.74 \pm$ & $45.68 \pm$ & $49.06 \pm$ & $8.32 \pm$ & $8.46 \pm$ & $8.27 \pm$ \\
& & 2.57 & 4.24 & 3.81 & 4.23 & 6.28 & 5.14 & 2.26 & 2.43 & 2.63 \\
\hline \multirow{2}{*}{$\mathrm{S}$ SAP } & \multirow{2}{*}{10} & $55.31 \pm$ & $83.25 \pm$ & $103.56 \pm$ & $104.56 \pm$ & $128.76 \pm$ & $164.87 \pm$ & $24.49 \pm$ & $31.58 \pm$ & $37.53 \pm$ \\
& & 6.57 & 6.14 & 8.84 & 11.34 & 12.16 & 12.23 & 4.57 & 4.62 & 6.32 \\
\hline \multirow{2}{*}{$\mathrm{SS}$} & \multirow{2}{*}{10} & $42.42 \pm$ & $68.61 \pm$ & $84.67 \pm$ & $72.43 \pm$ & $121.28 \pm$ & $135.27 \pm$ & $17.12 \pm$ & $21.89 \pm$ & $26.32 \pm$ \\
& & 6.38 & 4.43 & 5.27 & 8.68 & 9.45 & 11.43 & 3.85 & 4.32 & 3.12 \\
\hline
\end{tabular}

$* p<0.05$ SAP compared with SS 
FARMACIA, 2018, Vol. 66, 6

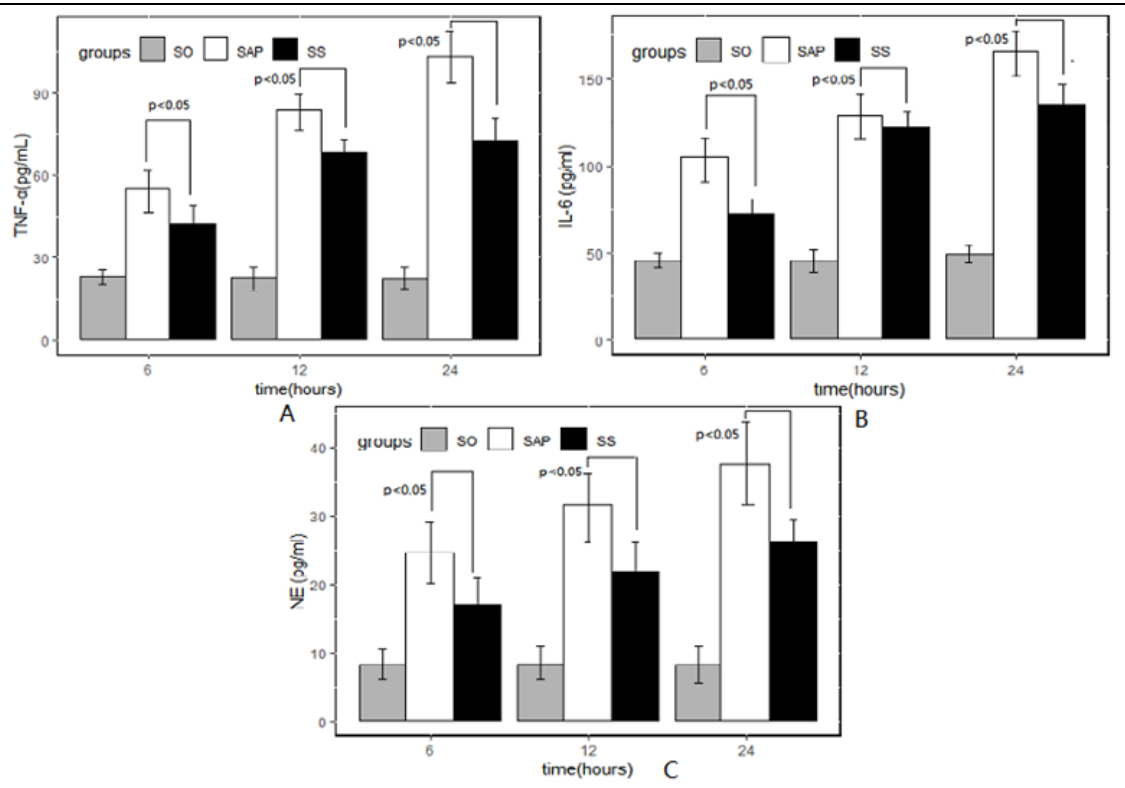

Figure 2.

Serum TNF- $\alpha$, IL-6, NE levels for the three time points $(6 \mathrm{~h}, 12 \mathrm{~h}, 24 \mathrm{~h})$ in each group

Serum IL-6 concentration was constant for each time point in the SO group, and increased in SAP and SS groups compared to SO group for each time point $(\mathrm{p}<0.05)$. Compared with the SAP group, IL-6 level decreased in SS group at each time point $(\mathrm{p}<0.05)$ (Table IV and Figure 2B).

Serum NE concentration was almost constant in SO group for each time point and increased in SAP and SS groups compared to SO rats for each time point $(p<0.05)$. In the case of SS group serum NE level decreased compared to the SAP group, for each time point $(\mathrm{p}<0.05)$ (Table IV and Figure $2 \mathrm{C})$.

Pancreatic tissue sections and scores

Macroscopic evaluation

In the SO group the pancreatic tissue had no significantly abnormal changes. Bowel movement was good and there was no exudation in abdominal cavity.

In the SAP group pancreatic oedema became more obvious over time. Pancreatic tissue haemorrhagic necrosis and haematogenous ascites also increased. The omentum majus and some saponification spots were noticed in the formed peritoneum. Initially, the colour change of pancreas was not obvious, but after 24 hours, the pancreatic tissue became dark brown, and the adhesion with adjacent tissues also increased. Gastric and intestinal processes had a significant expansion, and the intestinal numbness was particularly evident.

In the SS group, compared to the SAP group, the pancreatic modifications was not obvious at $6 \mathrm{~h}$ time. The general pathology reduced compared to the SAP group in different degrees at $12 \mathrm{~h}$ and $24 \mathrm{~h}$ time points. The ascites volume significantly diminished, and saponification spots were rare. The intestinal dilatation reduced at $6 \mathrm{~h}$ and $12 \mathrm{~h}$ time points, and peristalsis could be seen through the slight stimulation.

\section{Microscopic evaluation}

As shown in Figure 3, In the SO group the edges of pancreatic cells were obvious at all time points, and there were no abnormalities. The cells had no oedema and bleeding necrosis, and neutrophils were not observed in the tissue concentration phenomenon.

In the SAP group the arrangement of glandular tissue was chaotic. There was a lot of blood stasis in the interstitium and cell swelling was highly obvious. The phenomenon of neutrophils concentration occurred mainly over the large necrotic tissue area. The interstitial space was vague and the structure was disordered. In addition, the indicators gradually increased over time. In the SS group the interlobular space also gradually widened. Neutrophils infiltration in the intercellular space occurred. The acini began to swell and the necrosis decreased. The results were improved in the SAP group at all time points. Taking small focal necrosis as the main, eosinophilic body could be seen occasionally.

Table V

Pancreatic pathology scores for the studied groups at different time points $(6 \mathrm{~h}, 12 \mathrm{~h}, 24 \mathrm{~h})$

\begin{tabular}{|c|c|c|c|c|}
\hline Groups & $\mathrm{n}$ & $6 \mathrm{~h}$ & $12 \mathrm{~h}$ & $24 \mathrm{~h}$ \\
\hline SO & 10 & $0.47 \pm 0.43$ & $0.47 \pm 0.34$ & $0.73 \pm 0.54$ \\
\hline SAP & 10 & $7.94 \pm 1.47$ & $12.13 \pm 1.64$ & $13.43 \pm 1.17$ \\
\hline SS & 10 & $5.86 \pm 1.51$ & $8.36 \pm 1.73$ & $9.27 \pm 1.43$ \\
\hline
\end{tabular}

In the SAP model group, the degree of injury increased with time $(p<0.05)$. The scores were higher than the SO group for each time point $(p<0.05)$. The pathological score of SS group at each time point was lower than that of the SAP group at the same time point $(\mathrm{p}<0.05)($ Table $\mathrm{V})$. 


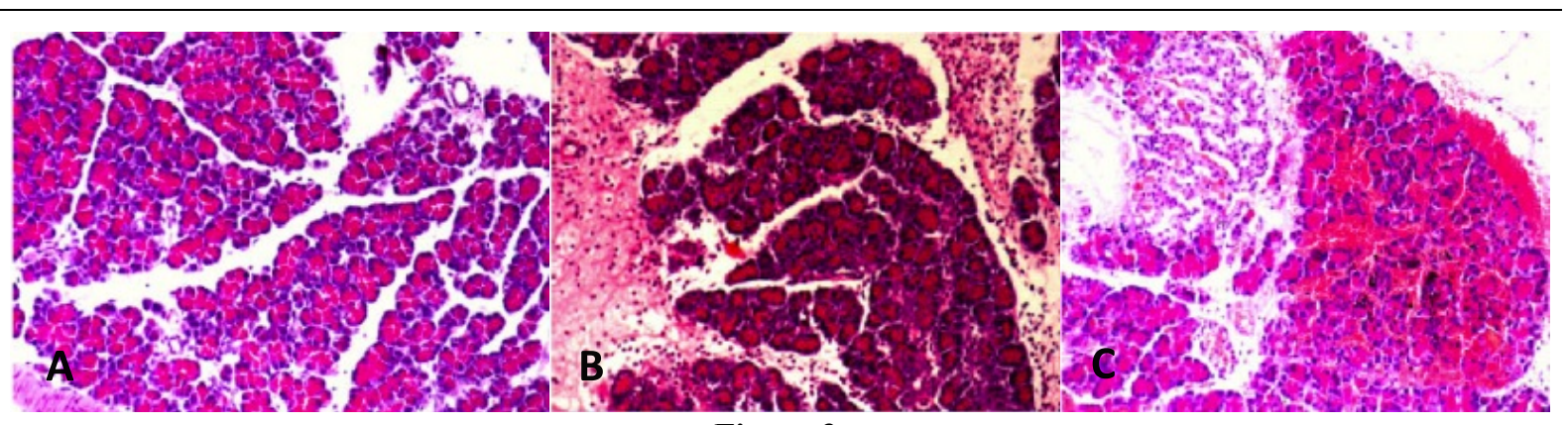

Figure 3.

HE staining of paraffin section of pancreas

A: pancreatic tissue of rats in group SO (x100); B: pancreatic tissue of rats in group SAP (x100); C: pancreatic tissue of rats in group SS (x100)

Renal tissue sections and scores

Microscopic evaluation

As shown in Figure 3, In the SO group the structure of glomerulus and kidney tubules had no obvious abnormal changes. The organizational structure was complete, and there was no tubular protein in the lumen. There was no degeneration necrosis in the epithelial cells and the mesenchyme had no congestion, nor oedema.

The capillary clearance of glomerulus widened in the SAP group. There was blood oozing in the renal capsule accompanied by inflammatory cell infiltration. There was obvious degeneration of the renal tubular epithelium. The cell edges began to blur, and the cavity was full of fluid. A small number of tubular epithelial cells necrosis and shedding could be observed, penetrating, interstitial congestion and oedema. Pathological damage aggravated over time.

In the SS group the infiltration of glomerular cells was reduced, but the infiltration of granulocytes remained in the periphery. The tubular epithelium was slightly blurred and the oedema diminished. Compared with the SAP group, the renal epithelial cells were reduced at different time points, but the improvement after $12 \mathrm{~h}$ was more obvious.

As shown in the Table VI, the scores for the SAP and SS groups were significantly higher than those of the SO group, for each time point $(\mathrm{p}<0.05)$. Compared to the SAP group, SS rats score decreased, without reaching the statistical significance $(\mathrm{p}>0.05)$. In time, the scores of the SAP and SS groups gradually increased $(\mathrm{p}<0.05)$.

Table VI

Kidney pathology scores in all the groups at different time points $(6 \mathrm{~h}, 12 \mathrm{~h}, 24 \mathrm{~h})$

\begin{tabular}{|c|c|c|c|c|}
\hline Groups & $\mathrm{n}$ & $6 \mathrm{~h}$ & $12 \mathrm{~h}$ & $24 \mathrm{~h}$ \\
\hline SO & 10 & $0.59 \pm 0.36$ & $0.74 \pm 0.35$ & $1.12 \pm 0.64$ \\
\hline SAP & 10 & $5.23 \pm 0.68$ & $9.37 \pm 1.13$ & $12.58 \pm 0.76$ \\
\hline SS & 10 & $4.57 \pm 0.74$ & $7.75 \pm 0.69$ & $9.45 \pm 0.82$ \\
\hline
\end{tabular}

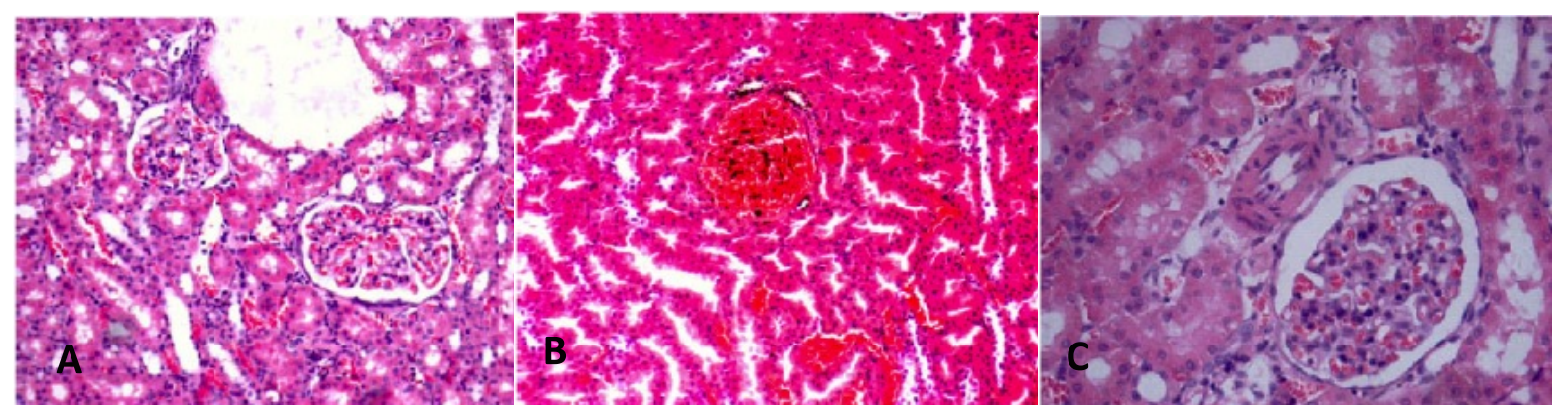

Figure 4.

Paraffin section HE staining of kidney tissue

A: kidney tissue of rats in group SO (x100); B: kidney tissue of rats in group SAP (x100); C: kidney tissue of rats in group SS (x200)

\section{$N F-k B$ activity in renal tissue}

The expression of NF- $\kappa \mathrm{B}$ proteins in the renal tissue appeared as brown and yellow on immunohistochemical colorations and was mainly located in the cytoplasm of the renal tubular epithelial cells. The expression of $\mathrm{NF}-\mathrm{kB}$ proteins in the renal tissue was very low for the SO group and increased in SAP and SS groups $(p<0.05)$. The expression of NF-kB proteins in the SAP group was higher than that of the SO group, for all the 3 time points $(p<0.05)$, but the expression of
NF-kB in SS group was lower than that of the SAP group for the same time point $(\mathrm{p}<0.05)$ (Figure 5). SAP is a very common clinical emergency and the prognosis and survival rates of patients are different. Currently, the incidence rate of SAP is gradually rising, being closely related with the improvement of living conditions and eating habits [9]. High-fat diet and hyperlipidaemia is an important factor that cannot be ignored. Simple gallstones caused by SAP 
FARMACIA, 2018, Vol. 66, 6

were rare, and microcrystalline cholesterol crystals became a new important risk factor [10].

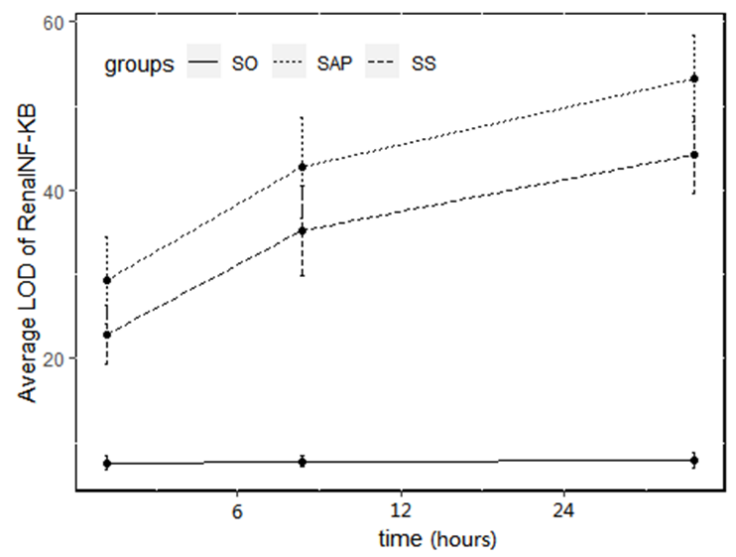

Figure 5.

NF-kB integral optical density ((IOD) average of the renal tissue for the three time points ( $6 \mathrm{~h}, 12 \mathrm{~h}, 24 \mathrm{~h}$ ) in each group of rats

Some time ago, physicians realized that SAP has a refractory and complex onset. Currently, due to intense researches on the pathogenesis of SAP, a new theory regarding the implication of "biliary micro-stone" in the development of acute pancreatitis become more and more credible [11]. SAP specific pathogenesis is not yet clear, and there still does not exist a specific and effective treatment [12]. There are many other theories regarding the aetiology of acute pancreatitis like the "activation theory of intestinal bacterial translocation", "theory of inflammatory cytokine cascade", the "trypsin digestion" and "pancreatic and multiple organ microcirculatory barrier theory", but no one can be generalized [13].

SAP is a medical emergency of acute abdomen because of its frequent high complications and high mortality [14]. Patients often die due to the systemic inflammatory response syndrome (SIRS) or multiple organ dysfunction syndrome (MODS) [15]. More and more attention has been paid to the involvement of extrapancreatic organs [16]. The most affected are the lungs and the kidneys [17]. Patients have a mortality rate between $40 \%$ and $60 \%$ after 7 to 10 days of hospitalisation, and single or multiple organ dysfunction were the main cause of death [18]. SAP patients with pancreatic nephropathy can develop renal failure, and the mortality rate can reach $80 \%$ [19]. More attention should be paid to those with APACHE II scores above 8 points, and those with level II according to Balthazar CT classification system [20]. According to Legrand et al. more than $50 \%$ of SAP patients present renal dysfunctions that need continuous renal replacement therapy to maintain the physiological functions, while at the same time, renal dysfunction is very low in SAP survivors [21]. This suggests that SAP-related renal impairment plays an important role in the course of SAP and it is a non-negligible prognostic factor.

In the current study it was observed that for the SAP rats, the levels of serum AMY, BUN and $\mathrm{Cr}$ were increased, being associated with the increase of serum TNF- $\alpha$ and IL- 6 levels at each time point. In the renal tissue the capillary clearance of glomerulus widened, being associated with blood oozing in the renal capsule and inflammatory cell infiltration. The extent of lesions was continuously enlarged at $12 \mathrm{~h}$ and $24 \mathrm{~h}$. The lumen was full of protein oedema fluid. This suggested that TNF- $\alpha$ and IL-6 levels can be associated with renal function and pathological changes, which are related with the course of renal damage.

NF-kB protein is an important transcription factor that regulates the expression of inflammatory mediators and immune genes. The expression of TNF- $\alpha$, IL-1, IL- 6 and other cytokines are regulated by NF-kB, and participate in the body immune inflammatory response. Under the stimulation of trypsin, an excessive inflammation stage appears in the organism leading to a misbalance between anti-inflammatory and proinflammatory cytokines. TNF- $\alpha$ and IL- 6 and other inflammatory factors determine the release and activation of NF- $\mathrm{kB}$ that is implicated in the further promotion and production of proinflammatory cytokines.

In the SO group the expression of inflammatory markers was almost absent. The expression of NF- $\kappa B$ in the SAP group was higher than that of the SO group $(p<0.05)$. The serum levels of TNF- $\alpha$ and IL-6 were consistent with the increase of the expression of $\mathrm{NF}-\kappa \mathrm{B}$ after $6 \mathrm{~h}$. All these suggest that the activation of NF-kB may play a role in the regulation of TNF- $\alpha$ and IL-6. NF- $\kappa$ B activation can be an association network through the inflammatory mediators. A large number of studies have shown that NF- $\kappa \mathrm{B}$ activation is the trigger point in the proinflammatory response, which is the core of SIRS and MODS, and can block the course of SAP and its related renal injury [22]. During the course of SAP, mononuclear macrophage system is over activated and inflammatory factors were produced [22]. The neutrophils begin to aggregate and activate under the action of inflammatory cytokines, releasing high amounts of neutrophil elastase (NE), which can degrade the collagen, laminin and matrix components in the extracellular or vascular wall. This can cause tissue damage and increase vascular permeability, promote the exudation of neutrophiles and the release of inflammatory factors such as TNF- $\alpha$, IL-1, IL-6, IL-8. In normal conditions, NE and endogenous inhibitors maintain a dynamic balance, and $\mathrm{NE}$ is inactivated. The balance between endogenous neutrophil elastase inhibitors and NE is broken during SAP, which results in the production of a large number of inflammatory factors and increases the tissue damage. Albuminase inhibitors, secretory leukocyte 
FARMACIA, 2018, Vol. 66, 6

protease inhibitors, $\alpha 2$ macroglobulin, and specific protease inhibitors are the major endogenous $\mathrm{NE}$ inhibitors. Sivelestat sodium, (N-[2-[4-(2,2-dimethylpropionic acid) benzene sulfonamide amino butyl sodium acetate), is a synthetic NE-specific inhibitor, mainly used for the treatment of systemic inflammatory response syndrome and the acute lung injury. It is used as a special treatment for SARS [23]. This medicine has a low molecular weight and possesses good oxidation tolerance, which can influence the tissue cell gap.

The results of this study showed that the levels of serum AMY after sivelestat sodium treatment significantly decreased compared to the SAP group of rats at different time points. The activity of BUN and $\mathrm{CR}$ in the SS group was also lower than that of the SAP group. Pancreas and kidney pathologies were also improved. These results suggested that sivelestat sodium can improve renal damage in SAP. The levels of inflammatory markers as NE, TNF- $\alpha$ and IL-6 in the SS group were significantly lower than those of the SAP rats at each time point $(p<0.05)$. It is suggested that sivelestat sodium can protect the renal function and inhibits NE, TNF-a and IL-6 production. The expression of NF- $\kappa \mathrm{B}$ protein in the renal tissue was not expressed or rarely expressed in the SO group of rats. The mean optical density of the SAP and SS groups was higher than that of the SO group $(p<0.05)$. The positive expression of NF-kB protein in the SAP group was higher than that of the SO group for the three time points $(p<0.05)$. The expression of $\mathrm{NF}-\kappa \mathrm{B}$ in the SS group was lower than that of the SAP group of rats $(p<0.05)$.

\section{Conclusions}

Sivelestat sodium can effectively improve the function of damaged kidney in the course of severe acute pancreatitis. Its mechanism of action is related to the reduction of inflammatory factors like TNF- $\alpha$ and IL-6, through the inhibition of NE release and the inhibition of NF-kB pathway activators in the renal tissue, in order to avoid secondary inflammatory injuries of the tissue.

\section{Acknowledgement}

This work was supported by Medical and Health Science and Technology Foundation of Zhejiang Province, China (No. 2013KYA170).

\section{References}

1. Unalp-Arida A, Ruhl CE, The Burden of Acute Pancreatitis in the United States Population. Gastroenterology, 2017; 152(5): S289.

2. Zhang WF, Li ZT, Fang JJ, Wang GB, Yu Y, Liu ZQ, Wu YN, Zheng SS, Cai L, Expression and clinical significance of rhubarb on serum amylase and TNF- alpha of rat model of acute pancreatitis. $J$ Biol Regul Homeost Agents, 2017; 31(3): 753-760.

3. Greenberg JA, Hsu J, Bawazeer M, Marshall J, Friedrich JO, Nathens A, Coburn N, May GR, Pearsall E, McLeod RS, Clinical practice guideline: management of acute pancreatitis. Can J Surg., 2016; 59(2): 128140.

4. Novovic S, Andersen AM, Nord M, Astrand M, Ottosson T, Jorgensen LN, Hansen MB, Activity of neutrophil elastase reflects the progression of acute pancreatitis. Scand J Clin Lab Invest., 2013; 73(6): 485-493.

5. Mikumo H, Yanagihara T, Hamada N, Harada E, Ogata-Suetsugu S, Ikeda-Harada C, Arimura-Omori M, Suzuki K, Yokoyama T, Nakanishi Y, Neutrophil elastase inhibitor sivelestat ameliorates gefitinibnaphthalene-induced acute pneumonitis in mice. Biochem Biophys Res Commun., 2017; 486(1): 205209.

6. Shimoda M, Iwasaki Y, Suzuki S, A protective effect of Sivelestat from ischemia/reperfusion injury in a porcine hepatectomy model. Int Surg., 2018: 1-29.

7. Li G, Jia J, Ji K, Gong X, Wang R, Zhang X, Wang H, Zang B, The neutrophil elastase inhibitor, sivelestat, attenuates sepsis-related kidney injury in rats. Int $J$ Mol Med., 2016; 38(3): 767-775.

8. Nicolae AC, Mitrea N, Drăgoi CM, Constantinescu MZ, Ciofrângeanu C, Bărboi G, Arsene AL, Murine studies regarding the variation of oxidative status in serum, hepatic and brain samples, after administration of some CNS active drugs. Farmacia, 2013, 61(4): 658-669.

9. Zhang WF, Li ZT, Fang JJ, Wang GB, Yu Y, Liu ZQ, Wu YN, Zheng SS, Cai L, Effect of mannose on the lung function of rats with acute pancreatitis. $J$ Biol Regul Homeost Agents, 2018; 32(3): 627-633.

10. Li G, Jia J, Ji K, Gong X, Wang R, Zhang X, Wang H, Zang B, The neutrophil elastase inhibitor, sivelestat, attenuates sepsis-related kidney injury in rats. Int $J$ Mol Med., 2016; 38(3): 767-775.

11. Kuliaviene I, Baniene R, Virketyte S, Kincius M, Jansen E, Gulbinas A, Kupcinskas L, Trumbeckaite S, Borutaite $\mathrm{V}$, Methylene blue attenuates mitochondrial dysfunction of rat kidney during experimental acute pancreatitis. J Digest Dis., 2016; 17(3): 186-192.

12. Ateyya H, Wagih HM, El-Sherbeeny NA, Effect of tiron on remote organ injury in rats with severe acute pancreatitis induced by l-arginine. Naunyn Schmiedebergs Arch Pharmacol., 2016; 389(8): 873-885.

13. Zhu Y, Tumor necrosis factor- $\alpha$ and procalcitonin level variations in the serum and their effects on organ function in patients with severe acute pancreatitis during infected stage. Pak J Pharmac Sci., 2017; 2: 30.

14. Jin M, Zhang H, Lu B, Li Y, Wu D, Qian J, Yang H, The optimal timing of enteral nutrition and its effect on the prognosis of acute pancreatitis: a propensity score matched cohort study. Pancreatology, 2017; 17(5): 651-657.

15. Gai YP, Zhao HN, Zhao YN, Zhu BS, Yuan SS, Li S, Guo FY, Ji XL, MiRNA-seq-based profiles of miRNAs in mulberry phloem sap provide insight into the pathogenic mechanisms of mulberry yellow dwarf disease. Sci Rep., 2018; 8(1): 812. 
16. Huggett MT, Culver EL, Kumar M, Hurst JM, Rodriguez-Justo M, Chapman MH, Johnson GJ, Pereira SP, Chapman RW, Webster GJ, Barnes E, Type 1 autoimmune pancreatitis and IgG4-related sclerosing cholangitis is associated with extrapancreatic organ failure, malignancy, and mortality in a prospective UK cohort. Am J Gastroenterol., 2014; 109(10): 1675-1683.

17. Cioboata R, Gaman A, Trasca D, Ungureanu A, Docea AO, Tomescu P, Gherghina F, Arsene AL, Badiu C, Tsatsakis AM, Spandidos DA, Drakoulis N, Calina D, Pharmacological management of non-alcoholic fatty liver disease: Atorvastatin versus pentoxifylline. Exp Ther Med., 2017; 13(5): 2375-2381.

18. Petrakis D, Vassilopoulou L, Mamoulakis C, Psycharakis C, Anifantaki A, Sifakis S, Docea AO, Tsiaoussis J, Makrigiannakis A, Tsatsakis AM, Endocrine Disruptors Leading to Obesity and Related Diseases. Int J Environ Res Public Health, 2017; 14(10): 1-18.

19. Selmi S, Rtibi K, Grami D, Sebai H, Marzouki L, Malathion, an organophosphate insecticide, provokes metabolic, histopathologic and molecular disorders in liver and kidney in prepubertal male mice. Tox Rep., 2018; 5: 189-195.

20. Guo Q, Li A, Hu W, Predictive factors for successful ultrasound-guided percutaneous drainage in necrotizing pancreatitis. Surg Endosc., 2016; 30(7): 2929-2934.

21. Legrand M, Jacquemod A, Gayat E, Collet C, Launay JM, Payen D, Failure of renal biomarkers to predict worsening renal function in high-risk patients presenting with oliguria. Int Care Med., 2015; 41(1): 68-76.

22. Legrand $M$, Jacquemod A, Gayat E, Collet C, Giraudeaux V, Launay JM, Payen D, Failure of renal biomarkers to predict worsening renal function in high-risk patients presenting with oliguria. Int Care Med., 2015; 41(1): 68-76.

23. Jiang KL, Ma PP, Yang XQ, Zhong L, Wang H, Zhu XY, Liu BZ, Neutrophil elastase and its therapeutic effect on leukemia cells. Mol Med Rep., 2015; 12(3): 4165-4172. 